\title{
PHRASEMES IN THE CONTEXT OF STUDENTS' COMMUNICATION
}

Phraseme application in all communication spheres and their appropriate performance forms are of particular interest to Slovak linguists against current dynamic tendencies in language communication. One of the necessary preconditions of successful communication is the knowledge and appropriate semantic interpretation of the most frequent phrasemes of a language. Since the language, culture and history are closely related, the phrasemes as specific lexical units reflecting life experience and wisdom of all generations help the language users in their overall personal advancement; including the phrasemes in the teaching of foreign languages is conditional on the differentiated level of language competence.

\section{Introduction}

As "the phraseology of any natural language represents one of the most interesting and complicated communication spheres", and a general level of language competence is evaluated according to the level of phraseological competence (see page 7 in [11]), it is obvious that phraseme application in all communication spheres and their appropriate performance forms are of particular interest to Slovak linguists against current dynamic tendencies in language communication. Apart from the existence of such intentional (though partial) research, there are following "neuralgic points" in Slovak phraseodidactics:

a) complex lexicographic compilation of phraseology;

b) sufficient research aimed at the phraseological competence of students at all school types and levels;

c) a set of phraseological units representing a necessary part of language users' equipment as a precondition of successful foreign language acquisition, including historical and cultural context.

P. Durčo's idea of the need to define a paremiological, or phraseological, minimum for all school stages, levels and types (see page 42 in [7]) seems to be well-founded in respect to the Slovak language education at all school levels and types considering the didactic function of phraseological units and their educational potential. The definition of a phraseological minimum, or phraseological minima, could have a positive impact not only on teaching the Slovak language as a mother tongue, but also as a foreign language (e. g. concerning the multiethnic situation in Slovak schools having begun). One of the necessary preconditions of successful communication is the knowledge and appropriate semantic interpretation of the most frequent phrasemes of a language (cf. J. Šindelářová's statement on the inevitable attention to the most frequent Czech phrasemes for elimination of communication barriers during Czech language teachers' training for multiethnic communication at schools - see page 167 in [22]).

\section{Exposition of somatic phrasemes in the usage of Slovak university students - future teachers}

In 2001 the Philosophical Faculty of the Catholic University (Ružomberok) was doing research on the vividness of somatic phrasemes to respond to the dynamic tendencies in phraseological stock and to the requirement of children and young people's phraseological competence development with regard to phraseodidactics. We had a sample of $100,1^{\text {st }}$ to $5^{\text {th }}$ year, students of pedagogy (Slovak Language and Literature).

The research of the university microsociety was intended to be in relation to elementary and secondary school students - their future Slovak language teachers who would participate in their communication (including phraseological) competence, became the research objects. The research probe considered the above-mentioned need to define the phraseological minimum during the analysis of results - 1. attention was paid to the very core of phraseological units containing the name of a human body part and so reflecting the anthropocentric character of the phraseology; 2 . an intensive corps of 500 somatic phrasemes required internal differentiation with a view to the verbal communication dynamics.

The processing of the results has brought an expected internal differentiation of the corps in the axes - central somatic phrasemes (active knowledge: I know and I use, index $<1.5$ ), postcentral somatic phrasemes (passive knowledge: I know and I do not use, index $<2.0$ ), peripheral somatic phrasemes (I do not know and I do not use, index $>2.0$ ). The results indicated that only $35 \%$ of phrasemes can be classified as the most frequent ones (central

\footnotetext{
* Dana Baláková1, Viera Kováčová1 ${ }^{1}$ Zdena Králová ${ }^{2}$

${ }^{1}$ Department of Slovak Language and Literature, Faculty of Arts and Letters, Catholic University in Ružomberok, Slovakia,

E-mail: Dana.Balakova@fphil.ku.sk, Viera.Kovacova@fphil.ku.sk

${ }^{2}$ Department of English Language and Literature, Faculty of Science, University of Žilina, Slovakia, E-mail: zdena.kralova@fpv.utc.sk
} 
somatisms), in $24 \%$ the phraseosemantic interpretation is known to the students, but the phrasemes do not belong to their active phraseological idiolect (post-central somatisms) and $41 \%$ of the phrasemes were totally unknown to the respondents (peripheral somatisms). The last ones are the necrotic phrasemes, in respect to the contemporary communication of university students and allusion to medical science. In connection with the discussed topic it is apparent that to specify the phraseological minimum constituents, it is necessary to take into consideration the central somatic phrasemes, as they are the best known and the most frequent ones in communication. ${ }^{1)}$

\section{The analysis of Slovak-Czech bilingualism of Slovak secondary school and university students from the view of phraseology}

The specific dimensions of phraseological research are from a linguodidactic view, conditional on the fact that phraseological competence is a standard, not only to the mother tongue, but also to a foreign language. Concerning the phraseological minimum, the capability of phrasemes to reflect the ethnocultural contrasts and universals comes into prominence. Appropriate semantic interpretation of phrasemes and confidence/proficiency in their application revises students' communication ability and affects the understanding a foreign language text.

To issue from the common characteristics and differences in the Slovak and Czech lexis (Slovak and Czech being the most related languages of the West Slavonic language group) and with regard to increasing divergent development of these languages after the split of the common republic, which primarily affects the society of children and young people living in less intensive contact with the other language (see also [13]), the analysis of Slovak-Czech bilingualism of Slovak secondary school and university students from the view of phraseology, would like to be a contribution to the phraseological competence research within the context of Slavonic languages.

The research was focused on the phraseosemantic interpretation of phrasemes selected from the Czech translation of T. Prachett's book "Men at Arms" from the "Discworld" series (translation J. Kantůrek) $[15]^{2)}$. The experiment was done with a sample of $198,1^{\text {st }}$ to $4^{\text {th }}$ year, grammar school students (Ružomberok, Žiar nad Hronom) and 284 university students in the 1 st through $4^{\text {th }}$ year of their study programme: Slovak Language and Literature (Philosophical Faculty of the Catholic University in Ružomberok) in 2006. The secondary school and university students analysed seven phrasemes and they then wrote an appropriate archiseme, or a Slovak equivalent of the Czech phraseological units:

1. Zatímco naši spoluobčané strádají pod jhem tyrana...

2. Chlápci v železe, kteř́ mydlí jeden druhého hlava nehlava, a tak dále.

3. Kromě toho si ted' i tak ukousl príliš velké sousto.

4. ...protože z žen takového postavení ho bolela hlava a při spatření mužŭ ho svědily pěsti.

5. Všichni se mu snažili uklidit z cesty.

6. ...víte, co dokáže, když si dá pár panáků..

7. Kápněte božskou!

During the initial results evaluation, we considered the overall success of the secondary school and university students' phraseological competence, correctness of the phraseosemantic interpretation of each phraseme, and success differentiation according to each level of the schools selected - with the mutual confrontation of the data obtained.

The probe into the secondary school and university students' interlanguage phraseological competence has brought forth interesting, and in relation to Slovak-Czech bilingualism, also satisfying results: $62 \%$ accuracy among the grammar school students and $70 \%$ among the university students reflects the ability to understand the substantial part of the analysed phraseme set properly.

The success or failure of both respondent groups analysing the phrasemes has been rather balanced (see Graph No. 1):

$\square$ grammar school students

$\square$ university students

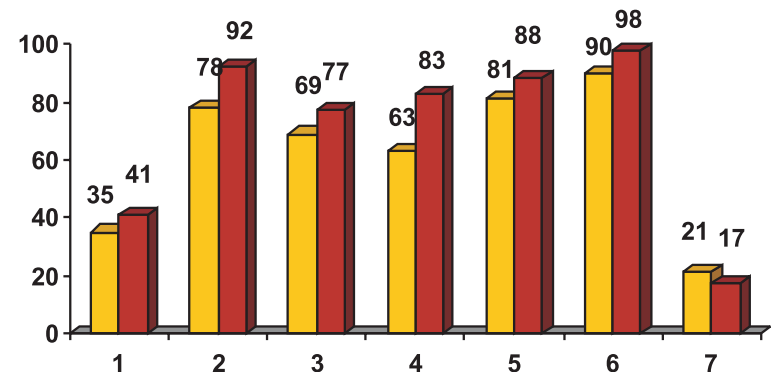

Graph No. 1 - comparison of success (in \%) of grammar school and university students for individual archisemes

A high percentage of success in both cases was reached in the phraseosemantic interpretation of the phraseme No. 6 dát si pár

\footnotetext{
${ }^{1)}$ According to the research results the following phrasemes belong to the central somatic phrasemes: vziat' (brat' a pod.) nohy na plecia, byt /iba, len/ kost' a koža, íst' (liezt') niekomu na nervy, medzi štyrmi očami, mat niečoho, niekoho /až/ po krk, brat si niečo /velmi/ $k$ srdcu, zlom väz, v zdravom tele zdravý duch, zamrzol mu úsmev na tvári, čo na srdci to na jazyku, etc.

${ }^{2)}$ Question of appropriate semantic interpretation of the phrasemes used in the Czech translation of an English fantasy literature writer T. Prachett's book attracted our interest because of its great success among Slovak readers. Regarding the fact that the Slovak book market reacted to Prachett's book later than the Czech one, the Slovak fantasy literature fans better know "Zeměplocha” from J. Kantůrek's Czech translation than "Plochozem".
} 
panáků (grammar school students $90 \%$, university students $98 \%$ ), and by contrast, there was a considerable prevalence of wrong answers in phraseme No. 1 strádat pod jhem tyrana (65\% failure among secondary school students, 59 \% failure among university students) and No. 7 kápnout božskou (79 \% failure among secondary school students and $83 \%$ failure among university students). The wrong answers given in the questionnaire, while attempting to find the proper archiseme, were frequently influenced by an inability to identify the meaning of two lexical components differentiated in relation to the Slovak lexis - strádat, jho (strádat pod jhem tyrana $)^{3}$, or by associations resulting from the previous experience with lexical units in non-phraseological use - kápnout, božsky (kápnout božskou). ${ }^{4}$

\section{Phraseological universals in relation to national}

Analysing the internal phraseme forms within confrontational phraseology is a good criterion for the identification of phraseological universals. From such a point of view, especially somatisms, as hyperactive elements of phrasemes, participate in total interlanguage synonymy (see page 35 in [6]). Scholars agree that the linguistic matters are not primary in internationalisation: ,...ona je vlastne odrazom civilizačných a kultúrnych vplyvov (...), ekonomického, politického, a žurnalisticko-publicistického diskurzu, no najmä technických procesov...” (see page 3 in [3]); ,je zpravidla expanzí civilizačných fenoménů, projevem technického pokroku, kulturních vlivü" (see page 10 in [10]). Phrasemes, as the expressions of mostly indigenous national culture, have often been transferred into other cultures where they have been domesticated (see page 8 in [11]). How much the dimension - national/international - is evident in the communicatively most exposed ${ }^{5}$, and currently the most vivid somatic phraseological units, is reflected in the research results (see [1], [2]). According to the research of 150 somatic phrasemes, a $96 \%$ correspondence to the Czech phrasemes, a $70 \%$ correspondence to the Russian phrasemes and a $64 \%$ correspondence to the French phrasemes of identically specified phrasemes can be stated.

$53 \%$ of the phraseological units were found in four languages (we mention the best known ones as an example) ${ }^{6}$ ) and nearly $25 \%$ were complied with the requirement of the domicile in the three phraseological stocks of natural languages. Approximately $21 \%$ occurred only in two languages (mostly Slovak and Czech) and only approximately $1 \%$ does not have the Slovak or the French equivalent (Graph No. 2).

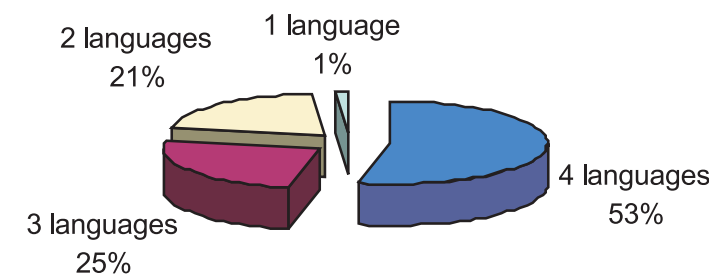

Graph No. 2 - Distribution of the most exposed phrasemes (150 units) in both communication spheres according to their occurrence in languages

3) To illustrate this we mention basic direction of respondents' thinking: lexeme jho - Slovak pronoun form jeho - on - pod ním (stretávajú pod ním tyrana, hladajú pod ním tyrana, strážia pod ním tyrana etc.); lexeme strádat - phonic form of verbs stretávat', strážit, strpiet' or even štrajkovat' (strpiet' na svete tyrana, stretávat niekoho pod inkognitom, štrajkujú pod sochou tyrana, etc.).

${ }^{4)}$ For example the lexeme kápnout associated alcohol (nalejte ten najlepší, čo doma máte, z najlepšieho, tej najlepšej, e. g. slivovice, naliat niečo, po čom sa človek cíti ako v raji); adjective božský apart from the application of the God's principle (Boh ich potrestá, klaňajte sa Bohu, zomriete rukou Božou, budete zatratení) associated perfectness of somebody/something (in general wisdom, shown up in expression, good meal, strong experience, winning, smell, etc., to the male respondents the opposite sex), etc.

${ }^{5)}$ We were interested whether the familiarity index of a phraseological unit (range 1.0 - 1.2) in university students' phraseological competence research or frequency of phraseological units ( 5 or more times) in press (200 copies of 5 Slovak daily newspapers) indicate a common origin (or motivation) of the phrasemes, and whether at least three foreign (Czech, French and Russian) lexicographically recorded equivalents exist ([16], [17], [18], [19], [20], [23], [5], [8]).

${ }^{6)}$ položit niekoho na lopatky - Cz: položit někoho na lopatky; R: положить кого на (обе) лопатки; F: faire toucher les épaules à qn; visiet' na vlásku - Cz: viset na vlásku; R: висеть наволоске; F: tenir à un cheveu;

brúsit' si zuby na niekoho, na niečo - Cz: brousit si (dělat si) zuby na někoho, něco; R: точить зубы на кого-Л., что; F: aiguiser ses dents sur qc; horúca hlava - Cz: horká hlava; R: горячая голова; F: tête chaude

dostat' (zrazit) niekoho na kolená - Cz: srazit někoho na kolena; R: поставить кого на колени; F: mettre qn à genoux; liezt' (íst') niekomu na nervy - Cz: jit/lézt někomu na nervy; R: лействовать на первы (кому); F: porter/taper sur les nerf à qn;

obrátit' sa (otočit' sa) chrbtom $\boldsymbol{k}$ niekomu - Cz: obrátit se, otočit se zády k někomu, k něčemu; R: повернуться спиной к кому-л; F: tourner le dos à q; neverit' vlastným očiam - CZ: nevěrit (nemoct uvěrit) svým (vlastním) (v)očím (svému zraku); R: неверить своим (собственным) глазам; F: nе раs en croire ses yeux;

strkat' (pchat') nos do niečoho (niekam) - Cz: strkat nos niekam; R: сунуть нос куда; F: metre (fourrer ) le (son) nez dans qch;

chytit niekoho za srdce - Cz: chytit někoho za srdce; R: брать за сердце; F: prendre qn par le coeur;

postavit' niekoho na nohy - Cz: postavit někoho na nohy; R: поставить кого на ноги; F: metre qn sur pied;

stratit' /svoju/ tvár - Cz: ztratit /svou/ tváŕ; R: потерять своё лицо; F: perdre la face;

zlé jazyky - Cz: zlé jazyky (zlí jazykové); R: злые языки; F: méchantes langues;

mat' niečo /už/v krvi - Cz: mít něco v krvi; R: иметь что в крови; F: avoir qch dans le sang;

ne/chciet' byt' v koži niekoho - Cz: nechtít být (bejt) v něči kůži; R: не хотеть быть (очутиться) в чьей шкуре; F: ne pas vouloir être dans la peau de qn; ukazovat' na niekoho prstom - Cz: ukazovat si na někoho prstem; R: покозывать на кого пальцем; F: montrer qn du doigt;

od hlavy po päty - Cz: od hlavy /až/ k patě (do paty); R: с головы до ног (до пят); F: de la tête aux pieds; 
In regard to the communicative-pragmatic turn in linguistics, the priority of current mother tongue teaching conception is the communicative competence of the graduates at all school types. Since language, culture and history are closely related, the phrasemes as specific lexical units, reflecting life experience and wisdom of all the generations, help the language users in their overall personal advancement. Including the phrasemes into the teaching of foreign languages is (besides the age) conditional on the differentiated level of language competence.

J. Pekarovičová points out the need of systematic presentation of phraseology to foreigners from the view of Slovak as a foreign language, in the context of ethnocultural and interlanguage relations; on the one hand, the specification of universals; and on the other hand, the specification of phraseological contrasts is necessary. The relevance of phraseodidactics, according to J. Pekarovičová, comes into prominence especially in connection with ethnocultural differentiations and contrastive intercultural communication, since from the pedagogical experience it is clear that, she says: „medzijazykové odlišnosti, kontrasty sú zdrojom potenciálnej interferencie pri porozumení i použivaní frazeologických jednotiek v prejave cudzincov" - even the multilingual phraseoconfrontation can be discussed in some cases within heterogeneous student groups. To acquire a communicatively relevant set of Slovak phrasemes is conditional on the methodology of selection and presentation (see pages $122-124$ in [14]).

\section{Conclusion}

Understanding the text is related to and conditional on the knowledge of extra-linguistic context - based on the two basic evo- lution tendencies in the lexis (the tendency to internationalisation and the tendency to nationalisation) in the era of globalisation and European integration (see page 144 in [4]). On the one hand, there are mutual civilisation influences and intercultural contacts; on the other hand, ethnocultural identity is being stressed - therefore it is necessary to increase the effectivity of phraseme acquisition, not only in education, but also after the institutionalized phase of education.

The communication sphere that significantly reflects the dynamics of social development is journalism - where the phrasemes, as the means of attractivity with aesthetic and cognitive function, are applied in their usual and also unusual, modified form, in which they often come into existence (phraseological neologisms). And therefore, the unusual form can be considered one of the substantial ones regarding the definition of the phraseological minimum of the mother tongue, the phraseological minimum of Slavonic languages and foreign languages in accordance with the requirement of the phraseological core (the fact which was also been reflected in our comparative research of the 150 most exposed phrasemes).

The popularity of phrasemes results from their pragmatic dimension - they are disposing units with a possibility of original individual transformation (foregrounding), marked by a striking character that completely names and evaluates the situation [11]. Phraseologically competent usage of such specific units by the communicants positively influences the utterance culture, communication efficiency and effect: phraseological units by means of their disposing form reflect the experience and wisdom of the generations and by means of their foregrounding they reflect an individual's esprit as well.

\section{References}

[1] BALÁKOVÁ, D.: Phraseological competence of university students (in Slovak), Slovo a obraz v komunikaci s dětmi, Komunikace s dětmi ve společné Evropě, Proceedings, odborný seminár, 26. 11. 2004, Ostrava, Pedagogická fakulta, Ostravská univerzita, 2004, pp. 86-88

[2] BALÁKOVÁ, D.: Phraseology in school (in Slovak), Odborová didaktika pri príprave učitela materinského a cudzieho jazyka, Ed. M. Ligoš, International Scientific Conference, Ružomberok 13.-14. 9. 2005, Filozofická fakulta Katolíckej univerzity, Ružomberok, 2006, pp. 171-181

[3] BOSÁK, J.: Internationalization processes today (in Slovak), Jazykovedný časopis, 1-2/2003, pp. 3-5

[4] BUZÁSSYOVÁ, K.: The development of Slovak lexis (mainly during last twenty years) (in Slovak), Letná škola prekladu, Ed. A. Keniž, Stimul, Bratislava, 2003, pp. 132-145

[5] Czech-Russian phraseological dictionary, Olomouc, UP, 2002, p. 659

[6] ḊURČO, P.: Motivation of phraseological units and typology of equivalents (in Slovak), Jazykovedný časopis, 40, 1/1989, pp. 33-41.

[7] ḊURČO, P.: Paremiography a paremiodidactics (in Slovak), K aktuálnym otázkam frazeológie, Konferencia Intersemiotický aspekt frazeológie, Nitra 7.-8. decembra 1999, Ed. E. Krošláková - L. Kralčák, Filozofická fakulta UKF, Nitra, 2001, pp. 29-48.

[8] French-Slovak phraseological dictionary, SPN, Bratislava, 1990, p. 1112

[9] GRÜNDELOVÁ, V., ŠKULTÉTY, J., TARABA, J.: French-Slovak phraseological dictionary, SPN, Bratislava, 1990, p. 1112

[10] KOŘENSKÝ, J.: Internationalization of current Slavonic languages - possibility or necessity? (in Czech), Jazykovedný časopis, 1$2 / 2003$, pp. 7-11.

[11] MIKO, F. et al.: Phraseology in school (in Slovak), SPN, Bratislava, 1989, p. 232

[12] MOKIENKO, V., WURM, A.: Czech-Russian phraseological dictionary, Red. E. Vysloužilová - L. Stěpanova, UP, Olomouc, 2002, p. 659 
[13] NÁBĚLKOVÁ, M.: The Slovak and the Czech language today. Contact or conflict (in Slovak), Slovenčina v kontaktoch a konfliktoch s inými jazykmi, Sociolinguistika Slovaca, 4. Ed. S. Ondrejovič, Veda, Bratislava, 1999, pp. 75-93

[14] PEKAROVIČOVÁ, J.: Slovak as a foreign language - object of applied linguistics (in Slovak), Stimul, Bratislava, 2004, p. 208

[15] PRATCHETT, T.: Men at Arms. Discworld (in Czech), Úžasná Zeměplocha, Talpress, Praha, 2001, p. 430

[16] Dictionary of Czech phraseology and idiomatics. Similes, Academia, Praha, 1983, p. 496

[17] Dictionary of Czech phraseology and idiomatics. Non-verbal expressions, Academia, Praha, 1988, p. 512

[18] Dictionary of Czech phraseology and idiomatics. Verbal expressions (A-P), Academia, Praha, 1994, p. 757

[19] Dictionary of Czech phraseology and idiomatics. Verbal expressions (R-Ž), Academia, Praha, 1994, p. 633

[20] The Slovak language dictionary. I. - VI. (in Slovak), Red. Š. Peciar, Vydavatel'stvo SAV, Bratislava, 1959-1968

[21] SMIEŠKOVÁ, E.: Little phraseological dictionary, (in Slovak), SPN, Bratislava, 1974, p. 296

[22] ŠINDELÁŘ́VÁ, J.: Training of the future teachers for multiethnic situation in Czech schools (in Czech), Odborová didaktika pri príprave učitela materinského a cudzieho jazyka, Ed. M. Ligoš, Filozofická fakulta, Katolícka univerzita, Ružomberok, 2006, pp. 163-181

[23] Large Slovak-Russian dictionary. I. - VI. 1. zv., Red. D. Kollár, 2.-6. zv., Red. E. Sekaninová, Veda, Bratislava, 1979-1995. 